\title{
Americký versus Evropský sen
}

\section{Dagmar Dušková}

Vedoucí práce: doc. Ing. Jana Boučková, CSc.

\section{Úvod}

\author{
America ... a design for the whole human race, \\ the last and greatest of all human dreams - or nothing. ${ }^{1}$ \\ Francis Scott K. Fitzgerald
}

Jaké jsou rozdíly mezi Americkým a Evropským snem? ${ }^{2}$ Proč právě sen Evropský nenápadně zastiňuje Americký sen, pro nějž Evropané opouštěli v 19. a 20. století svoji vlast a stali se přistěhovalci Severní Ameriky? Tato seminární práce je filozoficky zaměřenou úvahou s ekonomickým podtextem. Bude se zabývat nečekaným paradoxem: zatímco Americký sen stagnuje a stává se starým, nová generace Evropanů vytváří radikálně nový sen. Sen, který se začíná těšit pozornosti celého světa, protože lépe vyhovuje nástrahám globalizujícího se světa dvacátého prvního století.

\section{Americký sen}

\section{Exkluzivita Amerického snu}

První věc, kterou musíme v souvislosti s Americkým snem pochopit, je to, že od úplného počátku byl tento sen určen pouze pro Ameriku; hovoříme o tzv. exkluzivitě Amerického snu. Nikdy se nejednalo o sen, o který se měla Amerika dělit nebo který se měl exportovat do zbytku celého světa. Jeho síla spočívala v jeho partikularismu, ne v jeho univerzalizmu. Člověk tedy může jít za naplněním Amerického snu pouze na americké půdě. Jedinečnost tohoto snu na americké půdě je tím, co udělalo tento sen tak přitažlivý a Ameriku tak úspěšnou. Jeho exkluzivita je však nyní tím, co činí tento sen čím dál tím víc nevhodným ve světě, který se pomalu, ale jistě začíná propracovávat ke globálnímu vědomí.

\section{Vyvolený národ}

Mnoho Američanů se dnes stále pokládá za „,vyvolený národ“a Ameriku za půdu příležitostí. Věří, že Amerika je předurčena k velikosti a americká cesta je cestou Boží. Jejich veškerý úspěch se jeví jako důkaz toho, že byli skutečně vyvoleni. Věří, že Bůh je odměnil za jejich víru a udělal z nich nejmocnější národ na Zemi. Většina Evropanů pokládá tento aspekt Amerického snu za podivný, ne-li prrímo nahánějící strach. Představa, že Bůh nás učinil vyvolenými a náš národ zemí zaslíbenou často vyvolává v Evropanech nedůvěřivý úsměv, zejména mezi nenáboženskou evropskou populací, která již dlouho v Boha nevěří. Ale co Evropanům uniká je fakt, že je to právě tento element Amerického snu, který je hna-

1 Watzlawick, P.: Jak se neztratit? Amerika, Trango Pulishers, 1996.

2 Americký a Evropský sen jsou zde chápány jako názvy a proto jsou uváděny s velkými počátečními písmeny. 
cí silou amerického sebevědomí (pro mnoho Evropanů arogance), že Američané mohou „lámat skály,“ dokud je Bůh na jejich straně.

Každý školní den začínají americké děti slibem věrnosti k ,jednomu národu v Bohu.“ $\mathrm{Na}$ amerických bankovkách je napsáno: „In God we trust.“ Věříme v Boha. Zatímco se Amerika snaží oddělit církev od státu, soukromý život většiny Američanů se řídí vírou v Boha. Američané jsou nejnáboženštějšími lidmi ze všech průmyslově vyspělých národů na světě. Náboženská víra Američanů často zasahuje i do politické scény. Téměř polovina všech Američanů (48\%) věří, že Spojené státy mají zvláštní ochranu od Boha. ${ }^{3}$ Někteří významní evangeličtí protestantští vůdcové dokonce zastávají názor, že důvodem k útoku na World Trade Center (Světové obchodní centrum) a Pentagon, kde zemřelo téměř tři tisíce lidí, je ta skutečnost, že Bůh byl znepokojen americkými avanturistickými způsoby a odmítl dále poskytovat zvláštní ochranu jeho „vyvolenému národu.“

Velká většina americké veřejnosti (58 \%) tvrdí, že síla americké společnosti spočívá ve víře jejich lidí. Téměř polovina Američanů pak prohlašuje, že víra v Boha je nezbytným předpokladem pro dobré zásady. Šest z deseti Američanů tvrdí, že jejich víra je obsažena v každém aspektu jejich života. ${ }^{4}$

Mnoho Evropanů v Boha nevěří vůbec. Zatímco pro $82 \%$ Američanů je Bůh velmi důležitý, zhruba polovině všech Dánů, Norů a Švédů je Bůh lhostejný. ${ }^{5}$ Ve věcech víry je americký pohled bližší pohledu lidí z rozvojových zemí, zatímco od zbytku průmyslového světa se liší.

\section{Porovnání Amerického a Evropského snu}

Při porovnávání Amerického a nového Evropského snu zjistíme, že v mnoha ohledech je Evropský sen zrcadlovým protějškem Amerického snu. Můžeme tedy říci, že Americký a Evropský sen představují dvě diametrálně odlišné představy svobody a sociální jistoty.

\section{Svoboda, sounáležitost a sociální jistoty}

Američané lpí na negativní definici toho, co to znamená být svobodný a tudíž i sociálně zajištěný. Pro Američany byla svoboda dlouho spojována s autonomiï. ${ }^{6}$ Pokud je někdo autonomní, není závislý na ostatních nebo není zranitelný okolnostmi, které nemá pod kontrolou. Aby však byl člověk v Americe autonomní (nezávislý), potřebuje vlastnit majetek. Čím více majetku nahromadí, tím nezávislejší ve světě bude. Člověk se stává nezávislý tím, jak je sebejistý a spoléhá se sám na sebe. S bohatstvím přichází exkluzivita a s exkluzivitou sociální jistota.

Na druhé straně nový Evropský sen je založen na zcela odlišných předpokladech toho, co je podstatou svobody a sociální jistoty. Pro Evropany nespočívá svoboda v autonomii, ale v sounáležitosti. ${ }^{8}$ Být svobodný pro Evropany neznamená být sám a závislý sám na sobě, ale naopak svoboda je nalezena ve vytváření velkého množství interdepentních

3 Rifkin Jeremy: The European Dream, Jeremy P. Tarcher/Penguin, New York, 2004.

4 Rifkin Jeremy: The European Dream, Jeremy P. Tarcher/Penguin, New York, 2004.

5 Rifkin Jeremy: The European Dream, Jeremy P. Tarcher/Penguin, New York, 2004.

6 Autonomie $=$ samospráva, forma určité (omezené, relativní) nezávislosti, samostatnosti (v rámci většího celku)

7 Exkluzivní $=$ výlučný, výjimečný, mimořádný

8 Sounáležitý = vzájemně $\mathrm{k}$ sobě prríslušející, společně k něčemu patřící 
vztahů s ostatními. Pocit sounáležitosti umožňuje komunita, ${ }^{9}$ do které jedinec náleží a dává mu možnost prožít naplněný a smysluplný život. Čím více má člověk přístup ke komunitám, tím více možností a výběru má $\mathrm{k}$ tomu, aby žil naplněný život. Interdependentní vztahy ${ }^{10}$ vytvářejí inkuzivitu ${ }^{11}$ a tato hodnota vytvář́ pro Evropana pocit sociálních jistot.

\section{Ekonomický růst}

Americký sen klade důraz na ekonomický růst, osobní majetek a nezávislost. Na druhé straně nový Evropský sen se zaměřuje více na dlouhodobě udržitelný rozvoj, kvalitu života a interdependentní vztahy, tedy vzájemnou závislost. Americký sen holduje pracovní etice - kdo tvrdě pracuje, ten je respektován. Na druhé straně Evropský sen se zaměřuje více na volný čas a skutečně kvalitně strávený čas s rodinou a s přáteli. Americký sen je neoddělitelný od náboženského dědictví země a hluboké duchovní víry. Na druhé straně Evropský sen je ve svém jádru světský. Americký sen je asimilační - Američané spojují úspěch se zbavením se někdejších kulturních pout k rodné zemi původu a stávají se svobodnými představiteli tzv. amerického „,melting potu ${ }^{12}$ nejrůznějších ras a národností.“ Evropský sen je naopak založen na uchování kulturní identity člověka a životě v multikulturním světě. Americký sen je pevně spojen s láskou k zemi a patriotismem. Američan je velmi hrdý na to, že je Američan a je ochoten položit za svoji zemi i život. Evropský sen je více kosmopolitní a méně teritoriální. Američané jsou ochotnější nasadit v príípadě potřeby vojenské bezpečnostní jednotky kdekoli ve světě na ochranu toho, co slouží jejich vlastním životně důležitým zájmům. Evropané jsou zdrženlivější ve využívání vojenských bezpečnostních jednotek a místo toho dávají přednost diplomacii, ekonomické podpoře, pomáhají odvrátit konflikt a dávají přednost mírovým operacím $\mathrm{k}$ udržení pořádku. Američané mají sklony uvažovat lokálně zatímco evropské projevy loajality mají širší ráz a přecházejí od lokálního ke globálnímu. Americký sen je hluboce osobní (vztahuje se na jednotlivce) a zbytku lidstva se dotýká jen nepatrně. Evropský sen je expanzivnější a svou povahou systematičtější a tudíž i více spjatý s prosperitou celé naší planety.

Evropa má však také své stinné stránky. Přesto, že zde hovoříme o její inkluzivitě, různorodosti a uchování kulturní identity, Evropané se v posledních letech stali nepřátelštějšími $\mathrm{k}$ přijíždějícím imigrantům a těm, kteří hledají azyl. Na vzestupu jsou v Evropě i náboženská nesnášenlivost, antisemitismus a diskriminace muslimů a jiných náboženských menšin.

\section{Produktivita práce a pracovní doba}

Přesto, že evropská produktivita práce se pohybuje mezi 92 a $97 \%$ americké úrovně, př́ijem na osobu v EU je pouze $72 \%$ amerického prŕíjmu na osobu. ${ }^{13}$ Jak tedy vysvětlíme tuto odlišnost? Částečně je odlišnost zaprŕíčiněna nižším poměrem zaměstnanosti v Evropě k celkové populaci. Hlavní př́ičinou je však nižší počet odpracovaných hodin v EU.

Prakticky ve všech zemích EU dávají pracovníci přednost volnému času před delší pracovní dobou a vyšší mzdou. V drtivé většině evropských zemích je zákonná týdenní pracovní doba stanovena na 40 hodin týdně, včetně České republiky. V Belgii je pracovní

9 Komunita $=$ společenství, společenstvo

10 Interdependence $=$ vzájemná závislost

11 Inkluzivní $=\mathrm{v}$ to počítaný, uzavřený

12 Melting pot = tzv. „tavící kotel“, zakládá se na představě slévání různých tradic a kulturních praktik v jednu společnou univerzální kulturu.

13 Rifkin Jeremy: The European Dream, Jeremy P. Tarcher/Penguin, New York, 2004. 
týden 38 hodin a v Dánsku 37 hodin. Nejkratší pracovní týden má však Francie, kde v roce 1999 ustanovila francouzská vláda pětatřicetihodinový pracovní týden. ${ }^{14}$ Francouzský experiment byl obzvláště zajímavý, protože vyvrátil americké tvrzení, že tvrdá práce a dlouhá pracovní doba jsou nutné k dosažení vysoké produktivity a kvalitnějšího života pracujících. Produktivita Francie byla v roce 2002 vyšší než produktivita USA i přesto, že francouzští pracovníci si užívali mnohem více volného času. ${ }^{15}$ Je tedy zřejmé, že čerství a motivovaní pracovníci mohou za sedm hodin vyrobit stejně jako méně motivovaní a unavenější pracovníci za osm hodin. Francouzi snížili pracovní týden na pětatřicetihodinový částečně i proto, aby vytvořili nová pracovní místa. Uvažovalo se, že čím méně hodin týdně lidé pracují, tím lze zaměstnat další a tak snížit nezaměstnanost. To je sice pravda, na druhou stranu však rostou zaměstnavateli mzdové náklady a může tak ztrácet v boji s konkurencí na světových trzích. Dále čím více volného času Francouzi mají, tím se zvyšuje spotřeba a tím i útrata ve francouzských kavárnách, kinech, při sportovních soutěžích i v dalších oblastech zábavního průmyslu. Podrobnější přehled ukazatelů pracovní doby ve světě viz Příloha 1.

Ve většině zemí EU je dovolená stanovena zákonem a její průměrná délka v Evropě je šest týdnů. Ve Spojených státech však nejsou zaměstnavatelé ze zákona povinni dovolenou poskytovat. Nicméně, dvoutýdenní dovolená se v mnoha odvětvích stala pravidlem. Nejen, že je Evropa značně napřed v prosazování kratších pracovních týdnů, ale také ve vytváření novátorských přístupů $\mathrm{k}$ řízení lidských zdrojů dovolující pracovníkům pružněji přizpůsobovat práci a životní styl. Např́klad Belgie zavedla v lednu 2002 novou legislativu „Zákon o zápočtu odpracovaných let.“ Zákon je vytvořen tak, aby vytvářel podmínky pro pružnější rovnováhu mezi prací a soukromým životem. Podle tohoto nového zákona si mohou pracovníci vzít až jeden rok volna během své pracovní kariéry nebo přerušit práci, resp. ji snížit na poloviční úvazek aniž by porušili pracovní smlouvu a nebo pozbyli práv na sociální dávky. Aby dostal povolení přechodně opustit své zaměstnání, musí zaměstnanec informovat svého zaměstnavatele tři měsíce předem, avšak bez udání důvodu. Časový úvěr lze po dohodě se zaměstnavatelem prodloužit až na pět let. Dále mohou pracovníci požádat o tzv. tématickou dovolenou, aby mohli pečovat o nemocného člena rodiny nebo se starat o dítě. Každý pracovník se může rozhodnout pro snížení své pracovní doby o $20 \%$, což běžně znamená čtyřdenní pracovní týden. Zaměstnanci starší padesáti let mohou snížit svou pracovní dobu o pětinu až o polovinu po neomezenou dobu. ${ }^{16}$

Američtí zaměstnavatelé by byli nedůvěřiví při poskytování přerušení zaměstnání nebo poskytnutí časových úvěrů a navíc nechápou, jak belgické podniky dokáží při těchto přizpůsobivých pracovních plánech udržet konkurenceschopnost. A přesto znovu připomeneme, že v roce 2002 vykázali jak francouzští, tak belgičtí pracovníci vyšší produktivitu práce (měřenou jako objem výroby za hodinu) než jejich američtí kolegové. ${ }^{17}$

Díky tomuto časově neomezenému americkému př́istupu k práci říkají rádi Evropané, že „Američané žijí proto, aby pracovali“ zatímco „Evropané pracují, aby žili.“ Evropané se ptají, proč vydělávat víc peněz, když není dost času si jich užít? Jedna studie prokázala, že $37 \%$ Američanů dnes pracuje déle než 50 hodin týdně a $80 \%$ zaměstnaných mužů pracuje déle než 40 hodin týdně. Zatímco pracovní doba Američanů se prodlužuje, v Evropě je tomu naopak. Není potom žádným překvapením, že $70 \%$ amerických rodičů si stěžuje, že nemá dostatek času věnovat se dětem, zatímco 38 \% Američanů prohlašuje, že je ,stále ve

14 The Worldbank, Doing Business 2005.

15 Rifkin Jeremy: The European Dream, Jeremy P. Tarcher/Penguin, New York, 2004.

16 The Worldbank, Doing Business 2005.

17 Rifkin Jeremy: The European Dream, Jeremy P. Tarcher/Penguin, New York, 2004. 
spěchu, “a 61 \% tvrdí, že jenom velmi zřídka má času nadbytek. ${ }^{18} \mathrm{~S}$ tak malým množstvím času po práci využívá mnoho Američanů každou volnou chvíli k obstarávání nákupů, nošení prádla do čistírny, placení účtů a opravě domu. Nárůst pracovní doby se však musí zákonitě někde projevit. Podle zdravotnických odborníků se podepisují na zdraví Američanů např. choroby vyvolané stresem, obezita, infarkty, mrtvice, rakovina a mnoho dalších.

Rozdíl v tom, jak Evropané a Američané chápou dobrou ekonomiku, se odráží hlavně v délce pracovní doby na obou stranách Atlantického oceánu. Budeme-li měřit životní úroveň výší platu, tak jsou Američané o $29 \%$ bohatší než jejich evropské protějšky. Pokud však budeme hodnotit kvalitní život z hlediska volného času, průměrný Evropan má o 4 až 10 týdnů volna ročně víc. Otázkou zůstává, zda oněch $29 \%$ bohatství navíc dává Američanům větší radost a štěstí. Jak často manželky připomínají svým americkým manželům - workoholikům: „Nikdo nikdy na smrtelné posteli nelitoval, že nestrávil víc času v kanceláři.“

\section{Američané jsou z Marsu, Evropané z Venuše}

Američané a Evropané uvažují tak odlišně, že jeden jen stěží dokáže pochopit myšlení toho druhého. Inspirujeme-li se u britského politického teoretika Johna Graye, s trochou nadsázky můžeme říci, že „Američané jsou z Marsu a Evropané z Venuše.“ Zatímco americké vědomí má hluboké kořeny ve starém světě, sama cesta přistěhovalců přes oceán do země zaslíbené s cílem nově uspořádat svůj osud a pokusit štěstí u nich vedla k mnoha psychologickým rozporům.

Zatímco Američané mají větší tendence riskovat, Evropané jsou spíše k riziku averzní. Evropská komise ve studii podnikatelských hodnot z roku $2003^{19}$ zjistila, že dva ze tř́ Američanů by šli do podnikání i přesto, že by věděli, že mohou zkrachovat. Na druhé straně téměř jeden ze dvou Evropanů tvrdí, že by na sebe tento risk nevzali a raději by se nechali zaměstnat někým jiným. Když přemýšlíme nad tím, co znamená být Američanem, silná tendence riskovat je pravděpodobně první věc, která nás napadne.

Další základní odlišnost Američanů a Evropanů spočívá v tom, jak Američané a Evropané vnímají prostor a čas. Američané dychtí po exkluzivním prostoru. Každá osoba se snaží si vystačit sama a být nezávislá. Proto si Američané tolik zakládají na svém soukromí. Evropané naopak hledají inkluzivní prostor - být součástí větších komunit, zahrnujících rodinu a př́ibuzné. Pro Evropany je soukromí méně důležité než sounáležitost s ostatními. Pro Američany je čas směřován do budoucnosti a je chápán jako nástroj $\mathrm{k}$ využití nových prŕíležitostí. Evropané orientují čas více do minulosti a přítomnosti a využívají ho k upevňování a zušlech ování vzájemných rodinných a přátelských vztahů.

Krásný př́kklad, který dokládá tuto skutečnost, je vztah Američanů a Evropanů k mobilním telefonům. Tak např́íklad ve Švédsku se dívají na někoho, kdo telefonuje, jako kdyby osoba, se kterou telefonuje, byla fyzicky př́itomna ve stejném pokoji. Výsledkem je, že bavení se s někým ve Švédsku po telefonu, zatímco Švéd obědvá sám v restauraci je zcela přijatelné chování. Italové věří v neustálou konektivitu a mají rádi, když se jich ostatní kdykoliv dovolají. Nemají žádné zábrany v používání mobilních telefonů na jakémkoliv veřejném místě. Na rozdíl od Evropanů jsou Američané v používání mobilních telefonů opatrnější. Například obyvatelé New Yorku mají sklony používat telefony spíše k tomu, aby si vyř́idili své záležitosti, ale také považují telefonický hovor na veřejnosti za rušivý a vnímají ho jako porušování soukromého prostoru ostatních. Zatímco obyvatelé

18 Rifkin Jeremy: The European Dream, Jeremy P. Tarcher/Penguin, New York, 2004.

19 http://usinfo.state.gov/usa/infousa/facts/factover/ch5.htm 
San Francisca používají mobilní telefony při práci, ve volném čase a ke komunikaci s přáteli, jiní se obávají toho, že jsou neustále na př́ijmu a tím je narušeno jejich soukromí.

\section{Pomalý úpadek Amerického a vzestup nového Evropského snu}

Pád Amerického snu je $\mathrm{v}$ mnoha směrech neodlučně spjat se vznikem nového Evropského snu. Právě nedostatky starší americké vize dělají novou evropskou vizi tak atraktivní. Dá se říci, že Evropané vytvořili nejlidštější přístup ke kapitalismu a měli by se ptát, jaké nové nápady zrealizovat ke zlepšení tohoto systému. Udržování přiměřených sociálních výhod a snaha o vysokou kvalitu života pro všechny občany by měla být viděna Evropskou unií jako integrální úloha vybudování první skutečně udržitelné ekonomické velmoci na světě. Největší úkol, před kterým však EU v blízké budoucnosti stojí, je využití př́rodních a lidských zdrojů a budování silné kontinentální ekonomiky bez poškozování jejího dlouhodobého závazku k sociální a ekonomické spravedlnosti pro všechny občany.

O čem není pochyb je to, že Americký a Evropský sen se v jádru liší v otázce, jak nejlépe zabezpečit, aby každá osoba měla př́ležitost něčeho dosáhnout a realizovat se ve světě. Od samého počátku kladl Americký sen zodpovědnost na jedince, který se musí dokázat prosadit v ekonomice volného trhu, pouze s malou sociální podporou a jenom se zárukou bezplatného veřejného vzdělání. Na druhé straně Evropané věří, že společnost nese odpovědnost za méně nadané tím, že jim musí poskytovat sociální podporu, tak aby nikdo nebyl ,pozadu.“

Oba sny mají své silné a své slabé stránky. Evropané jsou často nařčeni Američany z toho, že nenesou dostatečnou osobní odpovědnost za svoje vlastní osudy. Na druhé straně Američané jsou často kritizováni Evropany za bezcitnost a za to, že se nestarají lépe o své sociálně slabší spoluobčany. Zajímavé je, že Evropané začínají brát $\mathrm{v}$ úvahu radu Američanů a zavádějí reformy, které jsou založeny na rovnováze mezi podněty ze strany jednotlivce a kolektivní odpovědnosti. Na druhé straně neexistují důkazy o tom, že Amerika by začala měnit svůj sen tím, že by do něj začlenila větší smysl pro společnou odpovědnost za kolektivní prospěch celé společnosti. Výsledkem je to, že někteří Američané se stávají bohatšími, zatímco mnoho ostatních Američanů chudne. V obou př́padech Americký sen trpí. Děti bohatších Američanů vyrůstají v luxusu a cítí se mocnější s právem na štěstí a méně ochotní tvrdě pracovat, něco obětovat a něčeho v životě dosáhnout. Americký sen se pro ně stává nekončící touhou po uspokojení, bez skutečného velkého účelu v životě. Pro ty méně nadané Američany, kteří stále ještě věří v Americký sen, a kteří se snažili znovu a znovu s velkým úsilím uspět, jen aby opět zjistili, že neuspěli, poci ují Americký sen jako krutou lež. Pro obě zmíněné skupiny postrádá Americký sen svůj respekt a obdiv.

Evropská unie není a ani nemůže být nápodobou Spojených států amerických. Evropa nemá centrální vládu, nejsou to Spojené státy evropské, ale uskupení, jež je organizováno na principu konsenzuální dohody a diskuse národních vlád, regiónů, rozhodování na úrovni nadnárodní, které ale nechybí ani ohledy na nižší celky. Evropská unie se stává důležitým gigantem, ačkoliv je ještě ve svých počátcích. Čtyři sta padesát pět miliónů lidí je občany Evropské unie, kteří reprezentují téměř 7 procent celkové světové populace. Zatímco je počet obyvatel EU menší než počet obyvatel Číny a Indie (obě populace mají přes 1 milión obyvatel), Evropská unie však předčí Spojené státy, které mají 293 miliónů obyvatel a tvoři 4,6 procent celkové světové populace, ale i Japonsko, které má 120 miliónů obyvatel, tudíž tvoří 2,1 procent lidské populace na Zemi. Evropská unie je nyní největší interní jednotný trh a stejně tak i největší obchodník se zbožím, ale i službami na světě. V roce 2000 Evropská unie utržila 590,8 biliónů eur, neboli 24 procent celkového světového obchodu se službami, v porovnání se Spojenými státy, které byly na druhém 
místě s objemem 550,9 biliónů eur a 22 procentním podílem na celkových světových službách. Japonsko bylo na třetím místě s 201,6 biliónů a 8 procentním objemem celkového obchodu. ${ }^{20}$ Navíc však Spojené státy vykazují obchodní ztrátu, jelikož dovážejí více zboží a služeb než vyvážejí. Na druhé straně Evropská unie vyváží více zboží a služeb než dováží.

Hrubý domácí produkt Evropské unie dosáhl 10,5 triliónů dolarů v roce 2003, což přesahuje hrubý domácí produkt Spojených států, který činí 10,4 triliónů dolarů. Faktem je, že hrubý domácí produkt Evropské unie se podílí téměř na 30 procentech světového hrubého domácího produktu, čímž se EU stává zastrašujícím soupeřem Ameriky v globální ekonomice. Hrubý domácí produkt EU je téměř 6,5 krát vyšší než v Číně. ${ }^{21}$

Hranice Evropské unie se stále ještě formují. Evropská unie, která má dnes 27 evropských členů ${ }^{22}$ s potenciálem přibrat další země, poroste a bude zabírat velké území mezi Finskem až po Středozemní moře, a od Irska až po Černé moře. Velká část Evropské unie bude záležet na schopnosti vytvořit efektivní vnitřní obchodní trh a komerční sféru. Evropská unie je $\mathrm{v}$ počátcích $\mathrm{s}$ vytvořením dopravního systému vedoucího přes všechny kontinenty, s integrovanou energetickou sítí, společnou komunikační sítí, jednotného trhu finančních služeb a společných podnikatelských zásad. Evropská unie založila tzv. Trans-European Network (TENs), pokrývající dopravu, energii, a telekomunikační sektory s cílem propojení celé Evropy v rámci jedné sítě. Cena za takovéto propojení Evropy bude vyšší než 500 biliónů dolarů a bude financována jednak vládami a jednak soukromým sektorem. ${ }^{23}$

Také Evropské vzdělávací programy jsou na programu EU. Evropská unie založila tři vysoce profilované vzdělávací programy: Socrates, Leonardo da Vinci, a Youth program. Socrates zakládá společné vzdělávací programy, vyzývá studenty a učitele k mobilitě mezi jednotlivými členskými zeměmi EU, a snaží se o harmonizaci curricula. Jedním ze Socratových projektů je projekt Erasmus, který poskytuje finanční prostředky více než jednomu miliónu evropských studentů ke studiu v jiné členské zemi. Dalším Sokratovým projektem je projekt Comenius, který sloučil více než 10 tisíc škol za účelem spolupráce při vzdělávacích snahách v rámci EU. Projekt Leonardo da Vinci pomohl více než dvou set tisícům mladých lidí zajistit pracovní zkušenost $\mathrm{v}$ jiné členské zemi. Youth program poskytuje mladým lidem mezi 15 a 25 věkem příležitost vykonávat dobrovolnické práce bud' lokálně nebo v jiné členské zemi EU. ${ }^{24}$

Pravděpodobně nejtěžším úkolem na cestě $\mathrm{k}$ evropské integraci je pomoc při překonávání velkých rozdílů $\mathrm{v}$ př́jmech a pracovních dovednostech mezi pracovníky západní a severní Evropy a pracovníky střední, jižní a východní Evropy. Vstup nových členů do EU z východních a jižních evropských zemí vyvolal v západních zemích obavu z př́livu levné pracovní síly do již vyspělejších evropských ekonomik. Také panují obavy, že společnosti, které podnikají v západní Evropě budou přesouvat svoji výrobu stále častěji do východní Evropy, kde je pracovní síla mnohem levnější. K tomuto jevu v určité míře již dochází. Západní Evropané se také obávají, že chudí imigranti přicházející z východu budou zatěžovat již zatížené daňové systémy. Tato obava je tak veliká, že mnoho z původních 15 členů EU přijalo různá omezení pro vstup pracovníků z východní Evropy do těchto zemí na několik let. Naopak východoevropané se obávají, že výrobky přicházející ze západní Evropy vytlačí domácí výrobce a zvednou ceny pro zákazníky.

20 Rifkin Jeremy: The European Dream, Jeremy P. Tarcher/Penguin, New York, 2004.

21 Rifkin J.: The European Dream, Jeremy P. Tarcher/Penguin, New York, 2004.

22 1. ledna 2007 vstoupilo do EU Rumunsko a Bulharsko. Česká republika vstoupila do EU 1. května 2004.

$23 \mathrm{http} / /$ ec.europa.eu/ten/transport/index_en.htm

$24 \mathrm{http}: / /$ ec.europa.eu/education/programmes/socrates/socrates_en.html 
Neméně důležitý je fakt, že anglický jazyk se pomalu, ale jistě stává jazykem Evropy. Použivá se již na mnoha universitách, speciálně v podnikatelském a vědeckém prostředí. Evropané si brzy budou moci vyměnit pracovníky, zboží a služby s jednoduchostí, přibližující se vnitřnímu americkému trhu. Nestane se to přes noc, ale proces evropské integrace ve společný vnitřní trh je již na své dobré cestě a zhruba $\mathrm{v}$ nastávajících pětadvaceti letech se vyrovná americké integraci.

\section{Závěr}

Americká materiální základna moderního pokroku se stává stále více věcí minulosti. Neomezená individuální akumulace blahobytu, pouze vlastní úspěch, konzumerismus, ignorace, násilí a vzrůstající chudoba ve Spojených státech amerických již nemůže naplňovat vize 21. století. Americký sen je mrtvý. Pozornost na sebe upoutává nový Evropský sen, který je silný, protože vytváří nové dějiny s ohledem na kvalitu života, jeho udržitelnost, harmonii a mír. Budoucnost je $\mathrm{v}$ evropské vizi, která dává přednost kvalitě života, hledání ,jednoty v rozmanitosti, “ udržitelnému vývoji, zábavě před tvrdou dřinou, právům př́rody před vlastnickými právy a celosvětové kooperaci před jednostranným uplatňováním moci. Evropa je na dobré cestě k budování silné kontinentální ekonomiky bez poškozování jejího dlouhodobého závazku k sociální a ekonomické spravedlnosti pro všechny její členy. Věřím, že i současná mladá generace evropského kontinentu je dobře připravena nést kolektivní odpovědnost, posilovat globální vědomí a usilovat o povznesení lidského ducha.

\section{Literatura}

[1] RIFKIN Jeremy: The European Dream. Jeremy P. Tarcher/Penguin, New York, 2004.

[2] ISBN 1-58542-345-9

[3] Kolektiv autorů: Akademický slovník cizích slov. Academia, nakladatelství AV ČR, 1997. ISBN 80-200-0607-9

[4] The Worldbank, Doing Business 2005.

[5] WATZLAWICK, P.: Jak se neztratit? Amerika, Trango Publisher, 1996. ISBN: 80-86053-05-9

[6] http://usinfo.state.gov/usa/infousa/facts/factover/ch5.htm

[7] http://www.infoplease.com/us/census/data/economic.html

[8] http://ec.europa.eu/ten/transport/index_en.htm

[9] http://ec.europa.eu/education/programmes/socrates/socrates_en.html

$[10]$ www.czso.cz 
Příloha 1: Ukazatele pracovní doby ve světě ${ }^{25}$

\begin{tabular}{|c|c|c|}
\hline \multicolumn{3}{|c|}{ Ukazatele pracovní doby ve světě } \\
\hline Země & $\begin{array}{l}\text { Max. počet hodin } \\
\text { nepřetržité práce }\end{array}$ & $\begin{array}{l}\text { Max. počet pracovních } \\
\text { dní v týdnů }\end{array}$ \\
\hline Austrálie & 24 & 7 \\
\hline Belgie & 12 & 6 \\
\hline Česko & 16 & 6 \\
\hline Dánsko & 13 & 7 \\
\hline Estonsko & 12 & 5 \\
\hline Finsko & 13 & 6 \\
\hline Francie & 10 & 6 \\
\hline Irsko & 13 & 6 \\
\hline Itálie & 9 & 6 \\
\hline Japonsko & 24 & 6 \\
\hline Korea & 20 & 6 \\
\hline Litva & 12 & 6 \\
\hline Lotyšsko & 12 & 6 \\
\hline Mad'arsko & 12 & 5 \\
\hline Malajsie & 20 & 6 \\
\hline Německo & 10 & 6 \\
\hline Nizozemí & 12 & 6 \\
\hline Norsko & 14 & 6 \\
\hline Nový Zéland & 24 & 7 \\
\hline Polsko & 13 & 6 \\
\hline Portugalsko & 10 & 6 \\
\hline Řecko & 12 & 5 \\
\hline Slovensko & 16 & 6 \\
\hline Španělsko & 9 & 6 \\
\hline Švédsko & 13 & 6 \\
\hline Švýcarsko & 15 & 6 \\
\hline USA & 24 & 7 \\
\hline Velká Británie & 13 & 6 \\
\hline
\end{tabular}

25 The Worldbank, Doing Business 2005. 